\title{
Dar rawšanī-ye bārān-hā : taḥlīl va barrasī-ye še $r-$ hā-ye Moḥammad-Reḍa Šafīì Kadkanī (M. Serešk). Tehrān, Našr-e Ketāb-e Nāder, 1381/2003, 321 p.
}

\section{Fereshteh Molavi}

\section{(2) OpenEdition}

1 Journals

Édition électronique

URL : http://journals.openedition.org/abstractairanica/6478

DOI : 10.4000/abstractairanica.6478

ISSN : 1961-960X

Éditeur :

CNRS (UMR 7528 Mondes iraniens et indiens), Éditions de l'IFRI

\section{Édition imprimée}

Date de publication : 15 mai 2006

ISSN : 0240-8910

Référence électronique

Fereshteh Molavi, « Dar rawšanī-ye bārān-hā : tahlīl va barrasī-ye še'r-hā-ye Mohammad-Reḍa Šafi'i Kadkanī (M. Serešk). Tehrān, Našr-e Ketāb-e Nāder, 1381/2003, 321 p. », Abstracta Iranica [En ligne], Volume 27 | 2006, document 321, mis en ligne le 02 janvier 2007, consulté le 25 septembre 2020. URL : http://journals.openedition.org/abstractairanica/6478 ; DOI : https://doi.org/10.4000/ abstractairanica.6478

Ce document a été généré automatiquement le 25 septembre 2020.

Tous droits réservés 


\title{
Dar rawšanī-ye bārān-hā : taḥlīl va barrasī-ye še'r-hā-ye Moḥammad- Reḍa Šafīìi Kadkanī (M. Serešk). Tehrān, Našr-e Ketāb-e Nāder, 1381/2003, $321 \mathrm{p}$.
}

\author{
Fereshteh Molavi
}

$1 \quad$ K. 'Ābedī is the author of several books and dozens of articles on contemporary poetry of Iran. He presents his study and critical analysis of Šafīî’s poetry in a book, entitled "Dar rawšanī-ye bārān-hā" - a verse taken from one of the poet's poem. Among modern Iranian literati, Šafiıi is well known not only as a poet, but also as a scholar in classical Persian literature (particularly poetry and mystic texts), as well as a translator with several translations from Arabic into Persian.

2 The book begins with a brief introduction, where the author describes his method in criticism, his writing style, and the contents of the book. This study has seven chapters, which are followed by a selective bibliography and an index of proper names. The titles of chapters are: I) A perspective of the poet's life and his works; II) An analysis of his poetry; III) In the realm of his mind; IV) The aesthetics of words; V) Some judgments on the poetry of M. Serešk; VI) Some samples of poems; and VII) Some samples of his views and literary studies.

3 The first chapter is a concise biographical account mainly dealing with the intellectual background of the poet and the process of his accomplishment as a poet and literary scholar. In the second one the author focuses on the theme, structure, and the style of the poet in twelve books of his poems published in a time span from 1344/1965 to 1376/1997. In the third chapter, the author discusses on the poet's journey from the traditional poetry and lyrics towards poetical senses and his final individual voice; the relation between ideas and poetry; his interest in history, nature, and human being; and social causes and cultural concerns. Chapter four covers imagination, language, 
music, and form. The following two chapters present the views of fourteen literati on Šafi'î's poetry, and thirty of his poems. Finally the last chapter introduces some of Šafî‘i’’s views on classical literature and modern poetry.

INDEX

Thèmes : 11.1.2. Littérature persane moderne

\section{AUTEURS}

\section{FERESHTEH MOLAVI}

Library of Congress - Washington 